\title{
Article
}

\section{Analyses of Xylem Vessel Size on Grapevine Cultivars and Relationship with Incidence of Esca Disease, a Threat to Grape Quality}

\author{
Renzo Foglia ${ }^{+}$, Lucia Landi ${ }^{+}$(D) and Gianfranco Romanazzi * (D) \\ Department of Agricultural, Food and Environmental Sciences, Marche Polytechnic University, \\ I-60131 Ancona, Italy; r.foglia@univpm.it (R.F.); 1.landi@univpm.it (L.L.) \\ * Correspondence: g.romanazzi@univpm.it \\ † Renzo Foglia and Lucia Landi share co-first authorship.
}

Citation: Foglia, R.; Landi, L.; Romanazzi, G. Analyses of Xylem Vessel Size on Grapevine Cultivars and Relationship with Incidence of Esca Disease, a Threat to Grape Quality. Appl. Sci. 2022, 12, 1177. https://doi.org/10.3390/ app12031177

Academic Editor: Silvia Guidoni

Received: 2 January 2022

Accepted: 18 January 2022

Published: 23 January 2022

Publisher's Note: MDPI stays neutral with regard to jurisdictional claims in published maps and institutional affiliations.

Copyright: (C) 2022 by the authors. Licensee MDPI, Basel, Switzerland. This article is an open access article distributed under the terms and conditions of the Creative Commons Attribution (CC BY) license (https:// creativecommons.org/licenses/by/ $4.0 /)$.
Featured Application: This work provides a reference support to further test the hypothesis that Vitis vinifera cultivars with wide xylem vessels may be more susceptible to esca disease and opens the way to alternative cultural practices and disease management strategies.

\begin{abstract}
Esca disease is one of the most important grapevine trunk diseases. It seriously reduces the quality and quantity of grapevine production, and results in a shorter vineyard lifespan. Previous studies have suggested that wide xylem vessel diameter favours development on grapevine of Phaeomoniella chlamydospora, one of the fungi involved in esca, thus affecting disease susceptibility. In this study, cultivars mainly originated from European countries, 27 white-berried and 24 redberried grapevine cultivars, were grown in the same experimental vineyard and were analysed for xylem vessel sizes (as diameter and frequency) for correlation with esca incidence. In this study, the cultivars showed significant differences in the xylem vessel parameters. However, no relationship was detected between vessel size and esca incidence in the field. Overall, white-berried cultivars showed wider vessel diameters than red-berried cultivars. The relationship between xylem vessel size in the red-berried and white-berried cultivars and incidence of esca symptoms is discussed. We suggest that vessel anatomy profiles can provide useful information for further investigations on grapevine genotype structure-esca incidence relationships.
\end{abstract}

Keywords: esca; grapevines; xylem vessel; vessel diameter; Vitis vinifera

\section{Introduction}

In commercial grapevine (Vitis vinifera) growing, vascular diseases (e.g., Eutypa dieback, Botryosphaeria dieback, and esca) are the major factors that can limit crop productivity, fruit quality and vineyard longevity [1-7]. The causal agents are a set of taxonomically unrelated fungi, which include Eutypa lata, Phaeoacremonium minimum (syn. P. aleophilum), Phaeomoniella chlamydospora, Diplodia seriata and Neofusicoccum parvum, as some of the most virulent and widespread [8-13].

Grapevines become infected primarily through pruning wounds [14], either in nurseries during the propagation phase [3] or in vineyards after planting in infested soils. These types of infection have been confirmed through $P$. chlamydospora, providing evidence that this pathogen is also soilborne [15]. Field observations indicate that to date there are no known grapevine cultivars that are resistant to these vascular diseases [5]. Therefore, the degrees of susceptibility range from highly susceptible to low susceptibility [16-24]. Usually, in plant genotypes that are more tolerant to vascular diseases, despite pathogen colonisation, the disease symptoms are less severe than in sensitive genotypes. This suggests that tolerant plants can neutralise the effects of virulence factors produced by these pathogens [25]. This affects the colonisation of the host by spores transported in the xylem 
by the sap flow and hyphal growth. These hosts that are more tolerant to pathogens rapidly compensate for the loss of xylem vessels due to pathogen compartmentalisation, by differentiating new functional vessels to maintain sufficient stem water conductivity, which might also explain the tolerance to wilt diseases [26,27]. In esca, which involves the woody tissues, the plant host can contain the spread of the pathogen through reduction of the spatial lumen of the plant xylem vessels, or by production of gels and development of tyloses that occlude the vessels and entrap the pathogen [27,28]. A spatiotemporal model of compartmentalisation of vascular wilt fungi in vessels has been hypothesised for annual plants, including tomato (Solanum lycopersicum) and cotton (Gossypium spp.) [25]. Among perennial crops, it was observed that in Ulmus genotypes affected by Dutch elm disease, which is a wilt disease caused by Ophiostoma novo-ulmi (C.M. Brasier) [29], the diameter of the xylem vessels has an important role in resistance to this wilt disease, whereby susceptible hosts have higher proportions of vessels of wide diameters, compared to resistant genotypes [30,31]. More recent studies have been carried out on xylem characteristics of avocado cultivars from Guatemalan, Mexican and West Indian botanical breeds susceptible to laurel wilt. These studies evidenced that avocado West Indian race wilt with a larger vessel diameter, and consequently a greater potential hydraulic conductivity, are more susceptible to laurel wilt [32]. Preliminary investigation of Pierce's disease of grape evidenced that two red-berried cultivars, 'Merlot' and 'Cabernet Sauvignon', from the occidentalis prole group, exhibited less disease symptoms and minor xylem vessel dimensions versus white-berried Thompson Seedless cultivar from the orientalis prole group [33]. In grapevine cultivars, the amounts of inoculated $P$. chlamydospora and the necrotic lesion lengths correlated with vessel size [34]. Then, using the grapevine as a model system, it was demonstrated that vessel diameter is a key determinant of the timing of their occlusion. [35,36]. Thus, it was suggested that xylem vessel diameter affects disease susceptibility in grapevine, to potentially explain the differences between the highly susceptible and tolerant hosts to esca disease [34,37]. However, the xylem anatomical properties linked to grapevine genotypes need to be investigated further to confirm such a xylem vessel size-esca relationship.

The goal of this study was to investigate the xylem vessel properties, such as vessel size and frequency, in 51 grapevine cultivars, 27 white-berried and 24 red-berried cultivars of $V$. vinifera of Italian national and international interest, with known average values of disease incidence in the field. The correlation of these anatomical properties with disease incidence was also investigated.

\section{Materials and Methods}

\subsection{Sampling Site}

The experimental trial was performed in an experimental vineyard located in Carassai (AP), at $158 \mathrm{~m}$ a.s.l., in the central Italy Marche region $\left(43^{\circ} 02^{\prime} 18.07^{\prime \prime} \mathrm{N} ; 13^{\circ} 39^{\prime} 39.41^{\prime \prime} \mathrm{E}\right)$ of the Agency for Services in the Agro-Food Sector of Marche Region (ASSAM). The vineyard was planted in 1989. The grapevines were grafted onto Kober 5BB rootstock (Vitis berlandieri $\times V$. riparia) and were grown under the cordon training system. Plants were grown on a slight and uniform slope along the hill. The plants were spaced at $3 \mathrm{~m}$ between rows and $1 \mathrm{~m}$ within rows. All the cultivars grown in the experimental vineyard had been examined for esca incidence according to visual inspections in 2008, based on the formula: disease incidence $(D I) I=(n / N) \times 100$, where " $n$ " represents symptomatic plants, and " $N$ " is the total number of plants [22].

\subsection{Experiment Setup}

In order to identify both the numbers of plants and wood stems from a 1-year-old initial productive spur (cordon) useful to gain significant results and maintain grapevine productivity, the experiment was set up. Therefore, in February 2017, during the dormancy period, the red-berried 'Montepulciano' and white-berried 'Passerina' $V$. vinifera cultivars were selected. The two cultivars showed plants with the same vigour. From each cultivar, five different plants were selected in five different areas on each block, and from each plant, 
three cordons were cut from the base and taken to the laboratory. Each stem contained 2-3 internodes and measured $8-15 \mathrm{~mm}$ in diameter and $30-50 \mathrm{~mm}$ in length. The middle internode position on the stem was used to measure vessel size.

\subsection{Assessment of Xylem Vessel Diameter and Frequency}

Measurements of tangential diameter and frequency of the vessels were performed on stem cross-sections, as described by [38]. For each segment, $5 \mathrm{~mm}$ internode fragments were fixed in a formaldehyde / acetic acid / ethyl alcohol (FAA) solution (5/5/9; SigmaAldrich, St Louis, MO, USA) for $48 \mathrm{~h}$ at $4{ }^{\circ} \mathrm{C}$, and then rinsed in deionised water and stored at $4^{\circ} \mathrm{C}$ in $80 \%$ ethanol. The cross-sections (100 $\mu \mathrm{m}$ thick) were made using a cryostat microtome (MICROM HM $505 \mathrm{E}$ ) at $-25^{\circ} \mathrm{C}$, and then stained with $0.05 \%$ Toluidine O solution, $\mathrm{pH} 4.3$ (Sigma-Aldrich). Measurements of vessel diameters and vessel densities were taken under an upright light microscope (Leica Microsystems CMS GmbH, Wetzlar, Germany) at $4 \times$ magnification, equipped with a digital camera (Leica Microsystems CMS $\mathrm{GmbH}$, Wetzlar, Germany), and using the application ruler of the X-Entry software (Alexasoft, Florence, Italy). For each section, the number of vessels and vessel densities were determined according to an automatic software grid measuring $1 \mathrm{~mm}^{2}$ positioned on the dorsoventral symmetry axis, (Alexasoft, Florence, Italy) (Figure 1). Tangential vessel diameters were calculated by measuring the average of the minimum and maximum diameters for each vessel considering at last 35 vessels from each stem, then 105 from each plant for a total of 525 vessels from each cultivar. Vessel density was calculated according to three cross-sections per stem and nine per plant by counting the average number of vessels per $1 \mathrm{~mm}^{2}$.

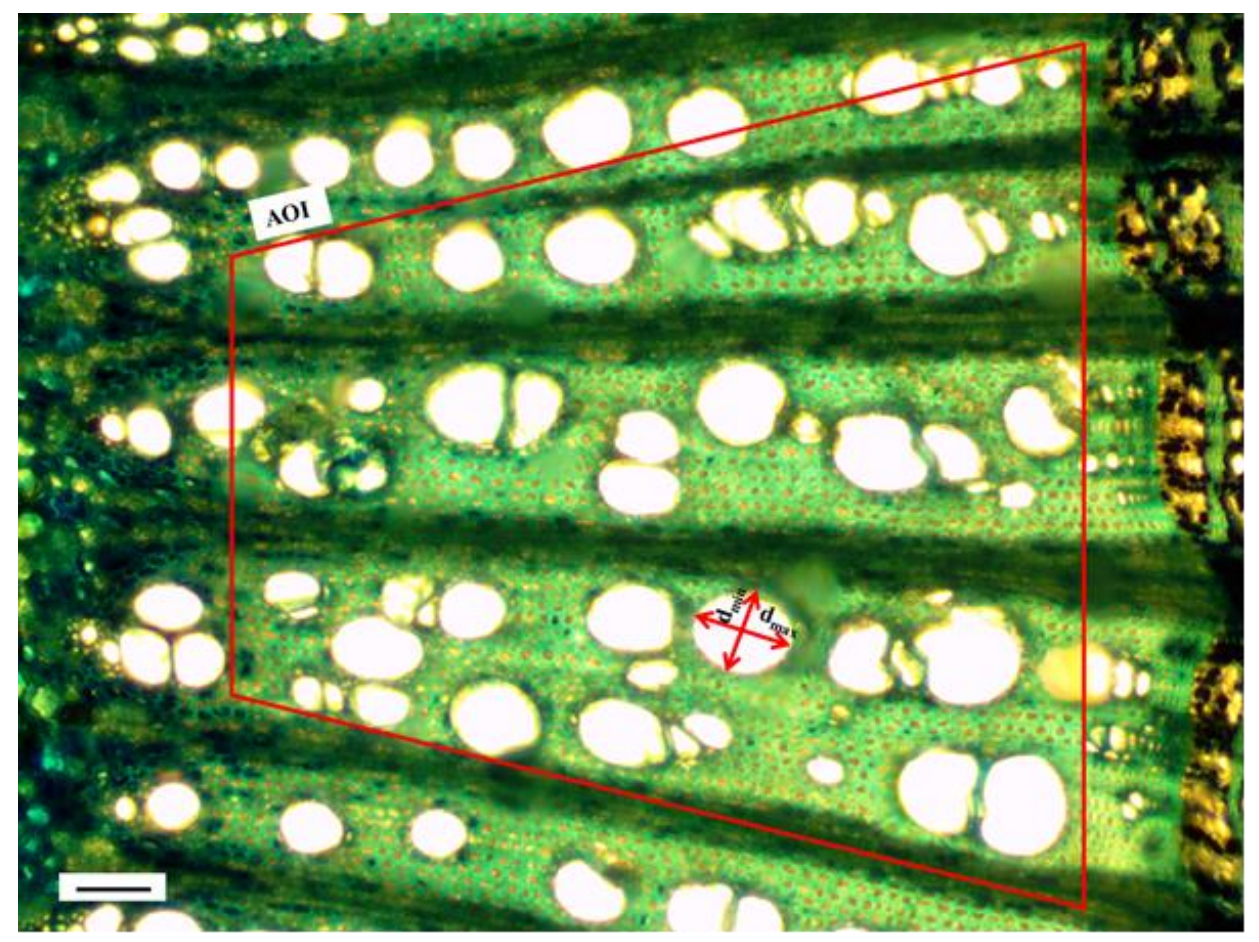

Figure 1. Illustration of representative vessel dimensions measured under the light microscope ( $4 \times$ magnification) on a transverse section from a grapevine cultivar. The maximum diameter $\left(\mathrm{d}_{\max }\right)$ and minimum diameter $\left(\mathrm{d}_{\min }\right)$ are easily measured on transverse sections. To calculate the vessel density, the total numbers of vessels per $1 \mathrm{~mm}^{2}$ were determined. The red polygon shows the area of interest (AOI). All vessels outside the AOI were excluded. Scale bar, $100 \mu \mathrm{m}$.

\subsection{Experimental Trial}

After preliminary test, in mid-February 2018 the xylem vessels size and density were investigated in 51 cultivars of $V$. vinifera, of which 24 were red-berried and 27 white-berried 
(Supplementary Table S1). Most of the cultivars, based on Vitis International Variety Catalogue VIVC [39], were originated from European countries, including Italy, France, Germany and the Balkans; while one cultivar each from South Africa and Slovenia was included. From each cultivar, five different plants were selected, and from each plant, one wood segment was cut from a 1-year-old initial cordon. The section of each stem (5 mm internode fragment) was processed as previously described. Then, after fixing the fragments, the tangential vessel density was calculated according to three cross-sections per plant, and the diameter was assessed for at least 120 vessels per cultivar. Nine diameter classes, in $20 \mu \mathrm{m}$ steps, were considered: $40-59 \mu \mathrm{m}, 60-79 \mu \mathrm{m}, 80-99 \mu \mathrm{m}, 100-119 \mu \mathrm{m}$, 120-139 $\mu \mathrm{m}, 140-159 \mu \mathrm{m}, 160-179 \mu \mathrm{m}, 180-199 \mu \mathrm{m}$, and finally, $>200 \mu \mathrm{m}$, as modified from [34]. The frequency of each diameter class was determined using Excel 2010 (Microsoft Corporation, Redmond, WA, USA). None of the cross-sections considered in the survey showed the presence of gels, tyloses, gums or other elements that are typical of vessels with occluded lumens.

\subsection{Statistical Analysis}

Data collected related to tangential vessel diameters (per each cultivar, $n=525$ vessel sections in the preliminary test and $n=120$ vessel sections in the experimental trial, were analysed), vessel densities (per each cultivar, $n=45$ vessel sections in the preliminary test were analysed) and vessel densities for the different diameter classes (per each cultivar, $\mathrm{n}=15$ vessel sections in the experimental trial were analysed). The data were subjected to one-way analysis of variance (ANOVA) followed by multiple comparisons of means, using Fisher's protected least significant difference (LSD) tests, at $p \leq 0.05$ (Statsoft, Tulsa, OK, USA). Finally, the datasets were tested for correlations using Pearson's coefficient (r), at $p<0.05$ (Statsoft, Tulsa, OK, USA).

\section{Results}

\subsection{Experiment Setup}

The preliminary investigation showed, for both 'Montepulciano' and 'Passerina' cultivars, high vessel diameter variability among plants but not among basal segments collected from each plant (Figure 2A,B). The vessel diameter average values were $95.2 \mu \mathrm{m}$ for 'Passerina' and $73.2 \mu \mathrm{m}$ for 'Montepulciano' cultivars (Figure 2C). This result highlighted high variability in vessel size among the plants of each cultivar; however, the significant differences detected between the two cultivars shown that 5 plants could be enough for vessel dimension and density investigations. Then, the non-significant difference among the vessel dimensions from three wood-stem 1-year-old initial cordons, suggested one wood stem could be representative of xylem vessel dimensions in each plant. This allowed us to preserve plants for grape production.

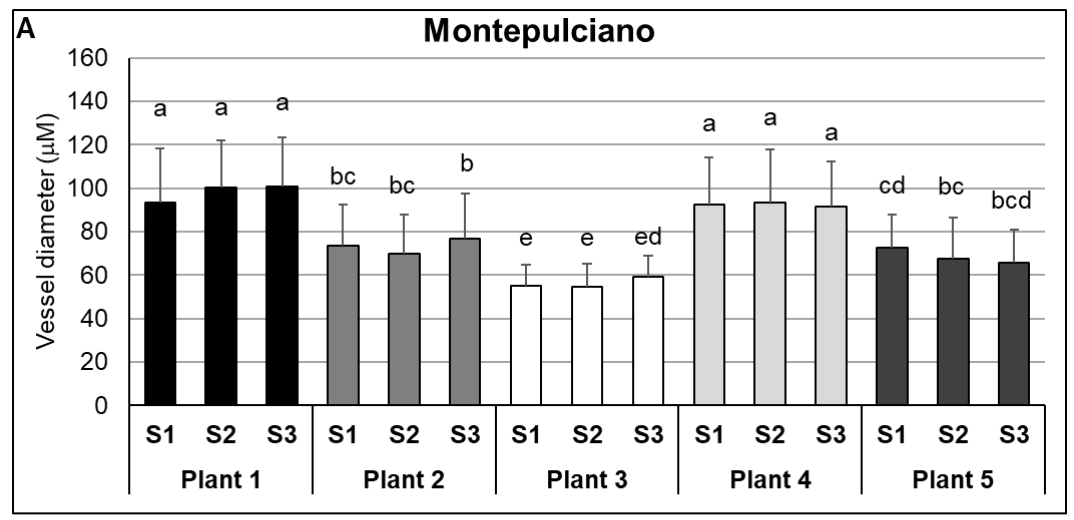

Figure 2. Cont. 

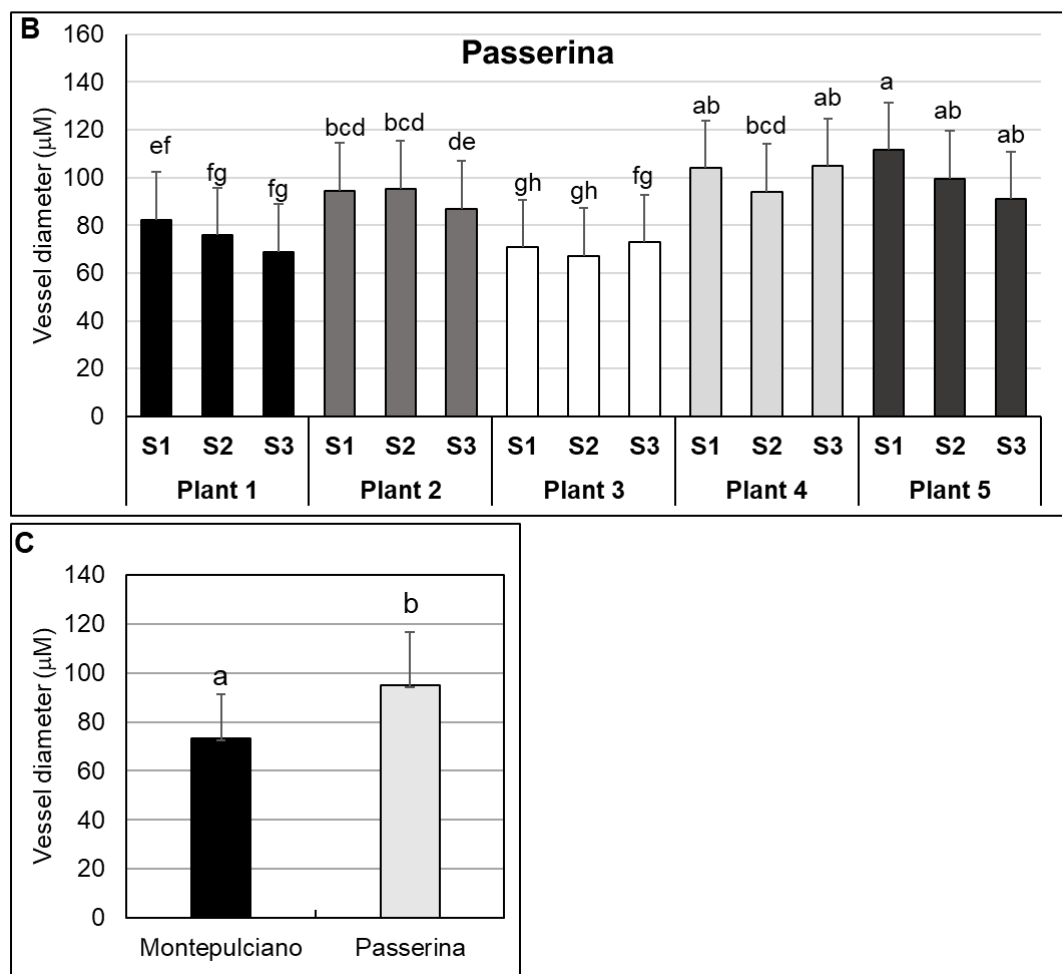

Figure 2. Quantification of vessel diameter detected in the preliminary test for 'Montepulciano' (A) and 'Passerina' (B) cultivar, relating to the singular stem (S) analysed from each plant. The average value per cultivar is also shown $(\mathbf{C})$. Data are means \pm standard deviation. Different letters above column indicate significant differences between cultivars (Fisher's tests; $p \leq 0.05$ ).

\subsection{Vessel Diameter}

High vessel diameter variability was recorded across all of the grapevine cultivars (Figure 3).
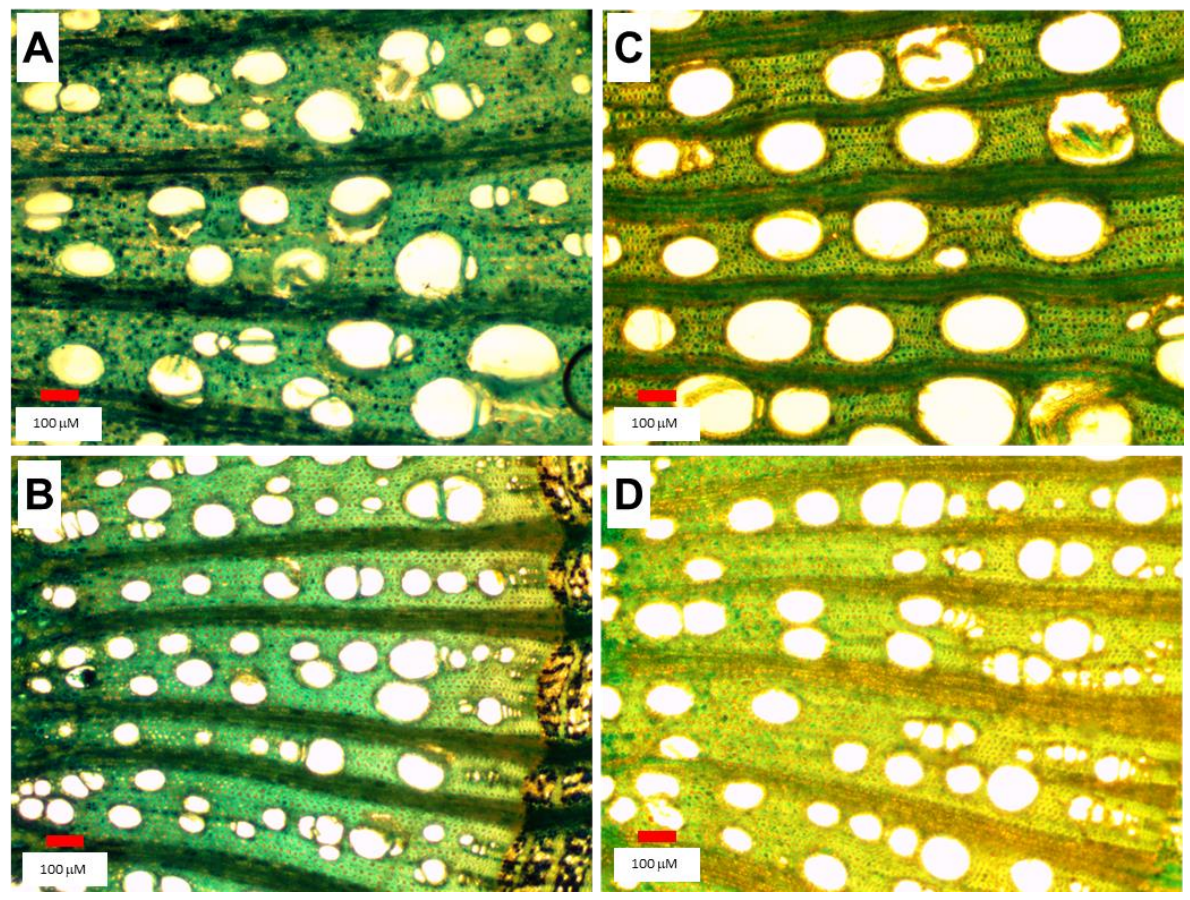

Figure 3. Representative cross-sections observed under the light microscope $(4 \times$ magnification) for the 'Sauvignon Blanc' R2 (A), 'Garofanata' (B), 'Nebbiolo' (C) and 'Montepulciano' (D) cultivars. Scale bar, $100 \mu \mathrm{m}$. All pictures are displayed at the same magnification. 
Red-berried cultivars-Related to the mean of all vessel diameter measurements from each grape cultivar, the 'Nebbiolo' showed the largest vessel diameter $(152.9 \mu \mathrm{m})$, followed by 'Limberger' $(123.4 \mu \mathrm{m})$. Conversely, 'Balsamina' and 'Montepulciano' showed the smallest diameters, at $75.4 \mu \mathrm{m}$ and $70.6 \mu \mathrm{m}$, respectively. All of the other cultivars showed intermediate diameters (Figure 4).

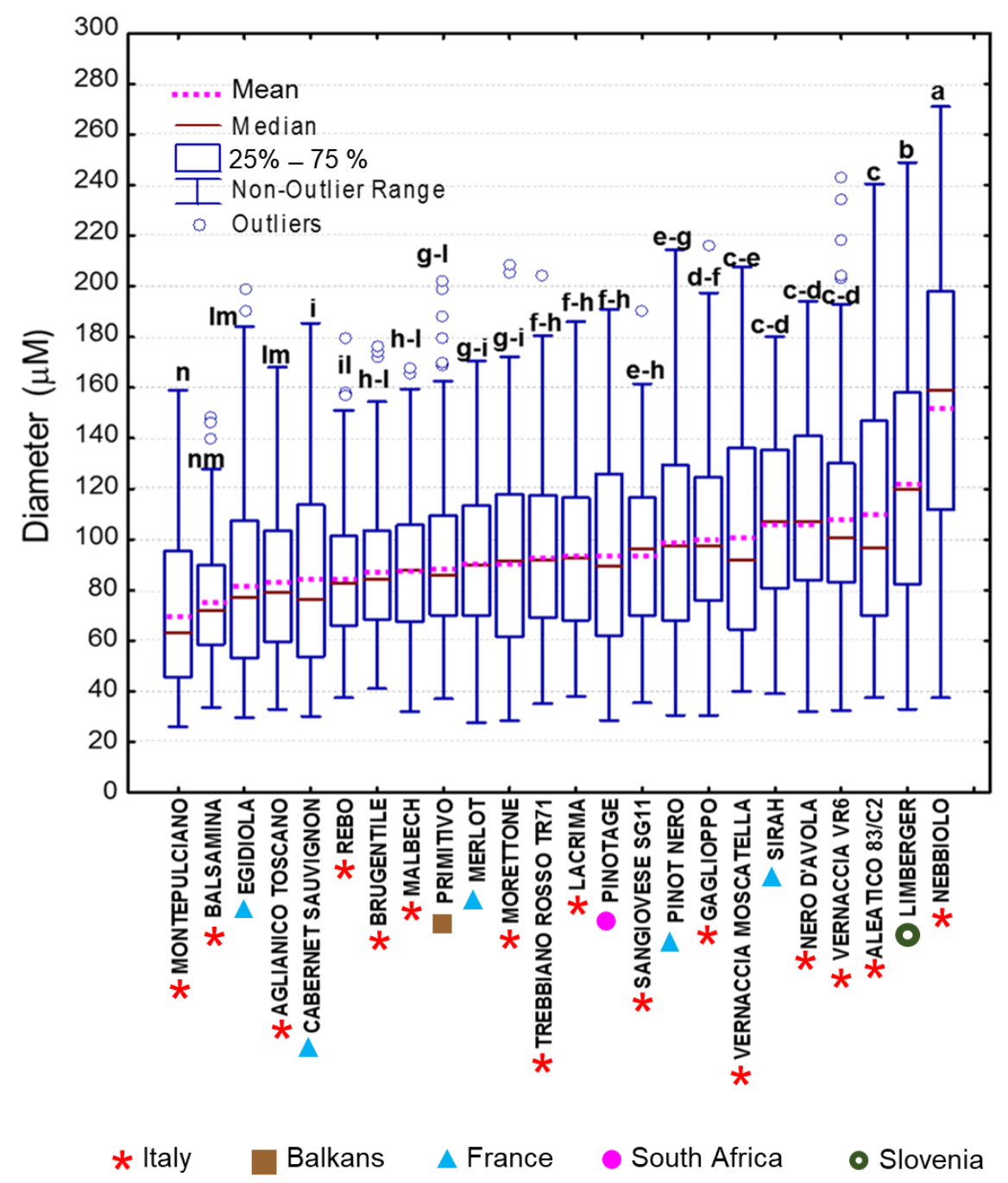

Figure 4. Box plot representing means of equivalent circle diameters measured in the 24 red-berried grapevine cultivars. The median and mean are represented by solid red and dotted pink lines, respectively. Top and bottom lines of the box correspond to the 25th and 75th percentiles of the data, respectively. Error bars represent the 10th and 90th percentiles. Circles represent outliers. Different letters above columns indicate significant differences between cultivars (Fisher's tests; $p \leq 0.05$ ). The geographic origin was added.

White-berried cultivars-In this group, the vessel diameters ranged from $160.4 \mu \mathrm{m}$ for 'Sauvignon Blanc' R2 to $81.9 \mu \mathrm{m}$ for 'Garofanata'. All of the other cultivars showed intermediate diameters (Figure 5). 


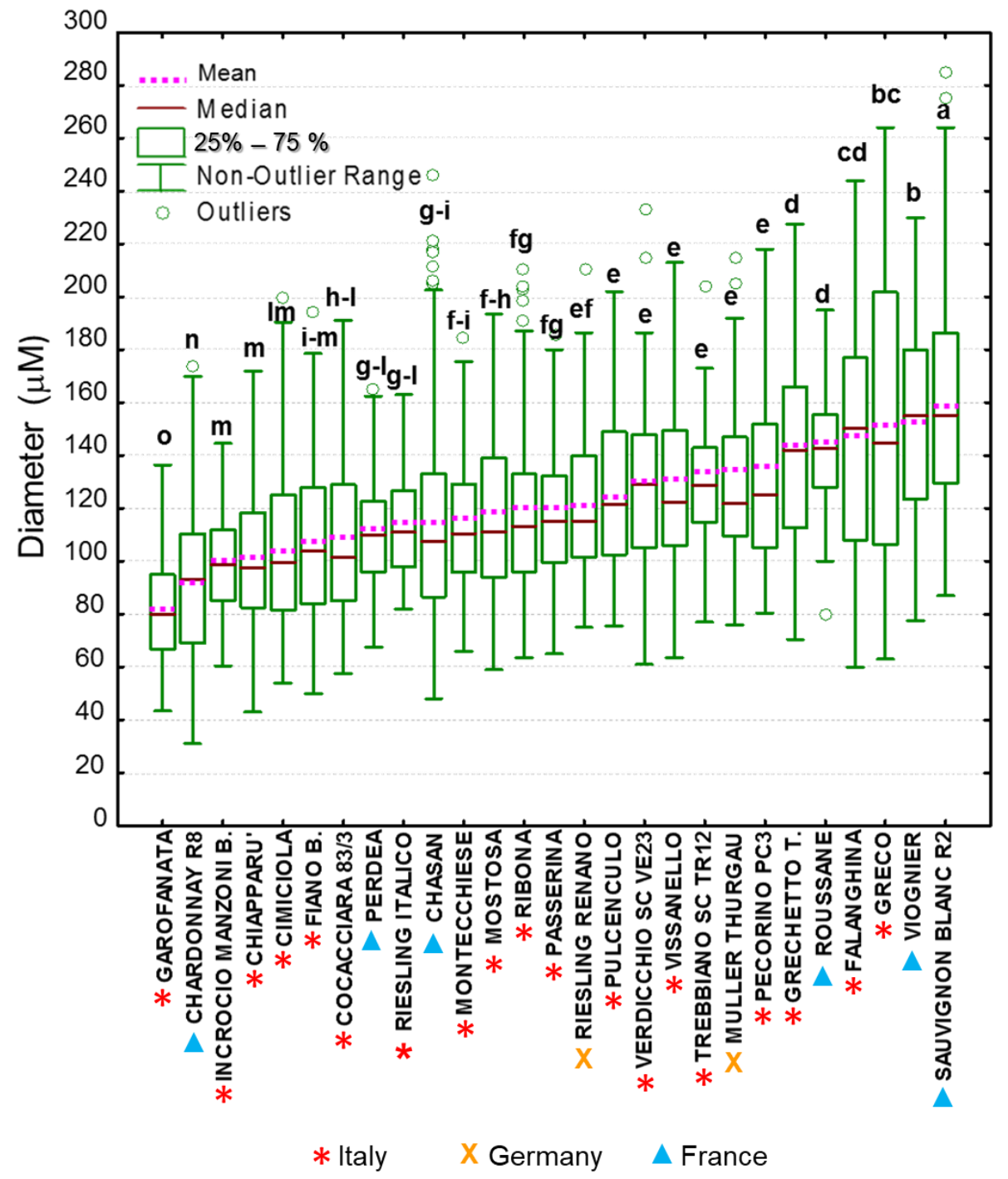

Figure 5. Box plot representing means of equivalent circle diameters measured in the 27 whiteberried grapevine cultivars. The median and mean are represented by solid red and dotted pink lines, respectively. Top and bottom lines of the box correspond to the 25th and 75th percentiles of the data, respectively. Error bars represent the 10th and 90th percentiles. Circles represent outliers. Different letters above columns indicate significant differences between cultivars (Fisher's tests; $p \leq 0.05$ ). The geographic origin from Vitis International Variety Catalogue database (www.vivc.de) [39] was added.

\subsection{Vessel Density and Number of Vessels per Diameter}

The density and frequency of xylem vessel size classes differed according to the cultivar. Vessel density was quantified as the average number of vessels per $1 \mathrm{~mm}^{2}$.

Red-berried cultivars-The 'Montepulciano' cultivar showed the highest value for vessel density ( 60.0 vessels $\mathrm{mm}^{-2}$ ), while 'Aleatico $83 / \mathrm{c}^{2}$ ' showed the lowest value ( 28.7 vessels $\mathrm{mm}^{-2}$ ). In the other cultivars, intermediate values were found, with high variability among the cultivars (Figure 6). For the vessel size frequency, in the red-berried cultivars, the most representative diameter classes were $60-79 \mu \mathrm{m}$ and 80-99 $\mu \mathrm{m}$. However, some cultivars showed the highest diameter classes, such as 'Sangiovese' SG11 (7.3 vessels), 'Trebbiano rosso' TR71 (6.2 vessels), 'Limberger' (4.6 vessels) and 'Syrah' (5.8 vessels), where the vessels were included in the 100-119 $\mu \mathrm{m}$ class, and 'Pinot nero' (5.2 vessels) and 'Nebbiolo' ( 6.8 vessels), where the vessels were included in the $>200 \mu \mathrm{m}$ class. Other cultivars showed lower diameter classes, such as 'Montepulciano' (7.8 vessels), 'Cabernet Sauvignon' (6.3 vessels), 'Pinotage' (5.2 vessels) and 'Egidiola' (8.2 vessels), which showed vessels in the $40-59 \mu \mathrm{m}$ class (Figure 6). 


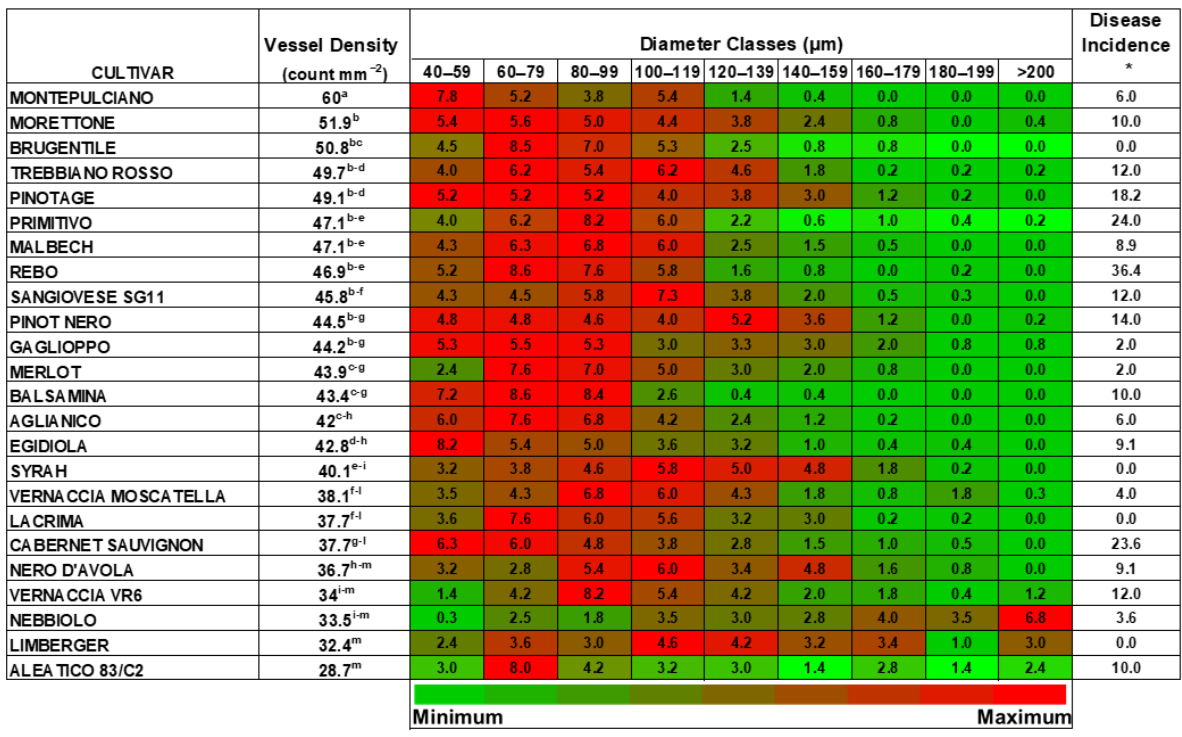

Figure 6. Quantification of vessel density and distribution per diameter class (vessels $/ \mathrm{mm}^{2}$ ) for the 24 red-berried grapevine cultivars. The differentiation in colour defines the minimum (light green) to maximum (light red) values. Different letters above columns indicate significant differences between cultivars (Fisher tests; $p \leq 0.05) .{ }^{*}$, esca incidence.

White-berried cultivars-In this group of cultivars, the highest vessel density was observed in 'Garofanata' ( 46.7 vessels $\mathrm{mm}^{-2}$ ), followed by 'Chiapparù' ( 43.0 vessels $\mathrm{mm}^{-2}$ ), while the lowest was observed for 'Sauvignon Blanc' R2 (18.3 vessels $\mathrm{mm}^{-2}$ ). All of the other cultivars had intermediate values (Figure 7).

\begin{tabular}{|c|c|c|c|c|c|c|c|c|c|c|c|}
\hline \multirow[b]{2}{*}{ CULTIVAR } & \multirow{2}{*}{$\begin{array}{c}\text { Vessel Density } \\
\text { (count } \mathrm{m} \mathrm{m}^{-2} \text { ) }\end{array}$} & \multicolumn{9}{|c|}{ Diameter Classes $(\mu \mathrm{m})$} & \multirow{2}{*}{$\begin{array}{l}\text { Disease } \\
\text { Incidence } \\
*\end{array}$} \\
\hline & & $40-59$ & $60-79$ & $80-99$ & $100-119$ & $120-139$ & $140-159$ & $\mid 160-179$ & $180-199$ & $>200$ & \\
\hline GAROFANATA & $46.7^{\mathrm{a}}$ & 4.0 & 10.3 & 8.8 & 5.0 & 1.0 & 0.0 & 0.0 & 0.0 & 0.0 & 8.0 \\
\hline CHIAPPARU' & $43.0^{\mathrm{a}}$ & 1.4 & 2.6 & 10.8 & 6.6 & 4.8 & 1.6 & 0.4 & 0.0 & 0.0 & 2.0 \\
\hline INCROCIO MANZONI B. & $37.5^{\mathrm{b}}$ & 0.0 & 4.3 & 11.0 & 9.0 & 4.5 & 1.0 & 0.0 & 0.0 & 0.0 & 30.9 \\
\hline CHASAN & $36.3^{\mathrm{bc}}$ & 1.4 & 4.2 & 6.8 & 5.2 & 4.6 & 3.4 & 0.6 & 1.0 & 1.6 & 14.5 \\
\hline COCACCIARA $83 / 3$ & $36.0^{b-d}$ & 0.3 & 4.8 & 8.0 & 7.0 & 3.3 & 2.8 & 2.8 & 0.5 & 0.0 & 12.0 \\
\hline CIMICIOLA & $35.4^{\text {be }}$ & 0.8 & 5.5 & 8.0 & 6.3 & 3.8 & 2.0 & 1.8 & 0.5 & 0.0 & 18.0 \\
\hline PERDEA & $34.8^{\mathrm{b}-\mathrm{f}}$ & 0.0 & 1.8 & 10.3 & 9.5 & 6.0 & 1.0 & 0.8 & 0.0 & 0.3 & 3.6 \\
\hline CHARDONNAY R8 & $34.4^{b-f}$ & 3.4 & 5.8 & 7.6 & 7.0 & 2.8 & 1.6 & 0.6 & 0.0 & 0.0 & 10.0 \\
\hline MONTECCHIESE & $33.0^{0.8}$ & 0.0 & 2.8 & 6.8 & 9.0 & 4.8 & 3.0 & 2.8 & 0.3 & 0.0 & 10.0 \\
\hline FIANO B. & $32.2^{\mathrm{d}-g}$ & 1.0 & 5.0 & 7.8 & 5.8 & 4.2 & 3.0 & 2.4 & 0.2 & 0.0 & 4.0 \\
\hline PASSERINA & $31.4^{e-h}$ & 0.0 & 1.2 & 6.2 & 10.2 & 6.6 & 3.0 & 2.2 & 0.4 & 0.0 & 34.0 \\
\hline VERDIC CHIO SC VE23 & $31.6^{6-h}$ & 0.0 & 2.4 & 3.6 & 4.6 & 7.8 & 6.4 & 3.2 & 0.6 & 0.4 & 3.6 \\
\hline FALANGHINA & $31.3^{f-h}$ & 0.0 & 2.2 & 3.8 & 5.0 & 2.6 & 4.2 & 5.2 & 2.8 & 4.0 & 10.0 \\
\hline RIESLING ITALICO & $30.5^{f-h}$ & 0.0 & 0.0 & 8.3 & 12.3 & 5.5 & 2.3 & 0.8 & 0.0 & 0.0 & 16.4 \\
\hline MULLER THURGAU & $29.7^{9-i}$ & 0.0 & 0.3 & 2.3 & 9.7 & 8.7 & 3.0 & 3.0 & 1.3 & 0.7 & 20.0 \\
\hline MOSTOSA & $29.5^{9-i}$ & 0.2 & 2.6 & 6.8 & 7.8 & 5.0 & 4.2 & 2.0 & 1.0 & 0.0 & 20.0 \\
\hline PULCENCULO & $29.3^{-i-i}$ & 0.0 & 0.8 & 5.4 & 7.8 & 5.0 & 6.4 & 2.2 & 1.8 & 0.2 & 12.0 \\
\hline RIBONA & $29.2^{\mathrm{g}-\mathrm{i}}$ & 0.0 & 2.2 & 6.2 & 8.4 & 6.6 & 3.6 & 0.4 & 1.2 & 0.6 & 12.0 \\
\hline VISSANELLOO & $28.1^{\text {hi }}$ & 0.0 & 2.2 & 3.6 & 7.8 & 6.2 & 4.6 & 2.6 & 1.8 & 0.6 & 10.0 \\
\hline GRECO & $28.0^{\text {h-i }}$ & 0.0 & 1.5 & 4.5 & 4.8 & 3.8 & 3.3 & 2.3 & 1.8 & 8.3 & 8.0 \\
\hline RIESLING RENANO & $27.6^{\mathrm{h}-\mathrm{m}}$ & 0.0 & 0.7 & 6.3 & 10.3 & 4.0 & 2.3 & 3.7 & 1.3 & 0.3 & 29.1 \\
\hline TREBBIANO SC TR 12 & $27.0^{\mathrm{h}-\mathrm{m}}$ & 0.0 & 0.3 & 2.7 & 7.0 & 10.3 & 8.0 & 1.3 & 0.0 & 0.3 & 16.0 \\
\hline PECORINO PC3 & $25.7^{i-m}$ & 0.0 & 0.0 & 5.2 & 8.0 & 6.2 & 4.2 & 3.8 & 1.6 & 0.6 & 20.0 \\
\hline GRECHETTO T. & $25.1^{1 \mathrm{~m}}$ & 0.0 & 0.6 & 3.6 & 5.0 & 5.0 & 6.2 & 4.4 & 2.4 & 2.2 & 4.0 \\
\hline VIOGNIER & $24.8^{1 m}$ & 0.0 & 0.4 & 2.4 & 2.8 & 5.6 & 4.6 & 5.6 & 4.8 & 3.0 & 18.2 \\
\hline ROUSSANE & $23.1^{\mathrm{m}}$ & 0.0 & 0.0 & 1.8 & 7.5 & 6.5 & 9.0 & 2.5 & 2.0 & 0.3 & 5.5 \\
\hline SAUVIGNON BLANC R2 & $18.3^{n}$ & 0.0 & 0.0 & 0.8 & 4.8 & 5.4 & 5.4 & 4.6 & 3.6 & 5.4 & 32.7 \\
\hline
\end{tabular}

Figure 7. Quantification of vessel density and distribution per diameter class (vessels $/ \mathrm{mm}^{2}$ ) for the 27 white-berried grapevine cultivars. The differentiation in colour defines the minimum (light green) to maximum (light red) values. Different letters above columns indicate significant differences between cultivars (Fisher tests; $p \leq 0.05$ ). ${ }^{*}$, esca incidence.

For the vessel size distribution, the most representative classes for most of the cultivars ranged from $80-99 \mu \mathrm{m}$ to $100-119 \mu \mathrm{m}$. However, except for 'Garofanata' with 10.3 vessels 
in the $60-79 \mu \mathrm{m}$ class, a number of cultivars showed greater vessel sizes corresponding to different classes. In detail, some cultivars showed vessel sizes corresponding to the 120-139 $\mu \mathrm{m}$ class, such as 'Sauvignon Blanc' R2 (5.4 vessels), 'Viogner' (5.6 vessels), 'Trebbiano' SC TR12 (10.3 vessels) and 'Verdicchio' SC VE23 (7.8 vessels). Other cultivars showed vessel sizes that corresponded to the 140-159 $\mu \mathrm{m}$ class, such as 'Sauvignon Blanc' R2 (5.4 vessels), 'Roussanne' (9.0 vessels) and 'Grechetto' $\mathrm{T}$ (6.2 vessels). In the $160-179 \mu \mathrm{m}$ class, there were 'Viogner' (5.6 vessels) and 'Falanghina' (5.2 vessels). Finally, in the $>200 \mu \mathrm{m}$ class, 'Sauvignon Blanc R2' (5.4 vessels) and 'Greco' (8.3 vessels) were observed (Figure 7).

Correlations between vessel anatomical characteristics and disease incidence detected on the same plants by [22] were investigated. For the red-berried cultivars, a negative correlation coefficient was found between vessel diameter and vessel density $(r=-0.666)$ (Figure 8A) while the correlation was weak between vessel diameter and disease incidence $(\mathrm{r}=-0.4451)$ (Figure 8B), and between disease incidence and vessel density $(\mathrm{r}=0.56195)$ (Figure $8 \mathrm{C}$ ). For the white-berried cultivars, a negative correlation coefficient was observed between vessel diameter and vessel density $(r=-0.8577)$ (Figure $8 D)$, while a weak correlation was observed between vessel diameter and disease incidence $(r=0.13588)$ (Figure 8E), and between disease incidence and vessel density $(r=-0.2779)$ (Figure 8F).

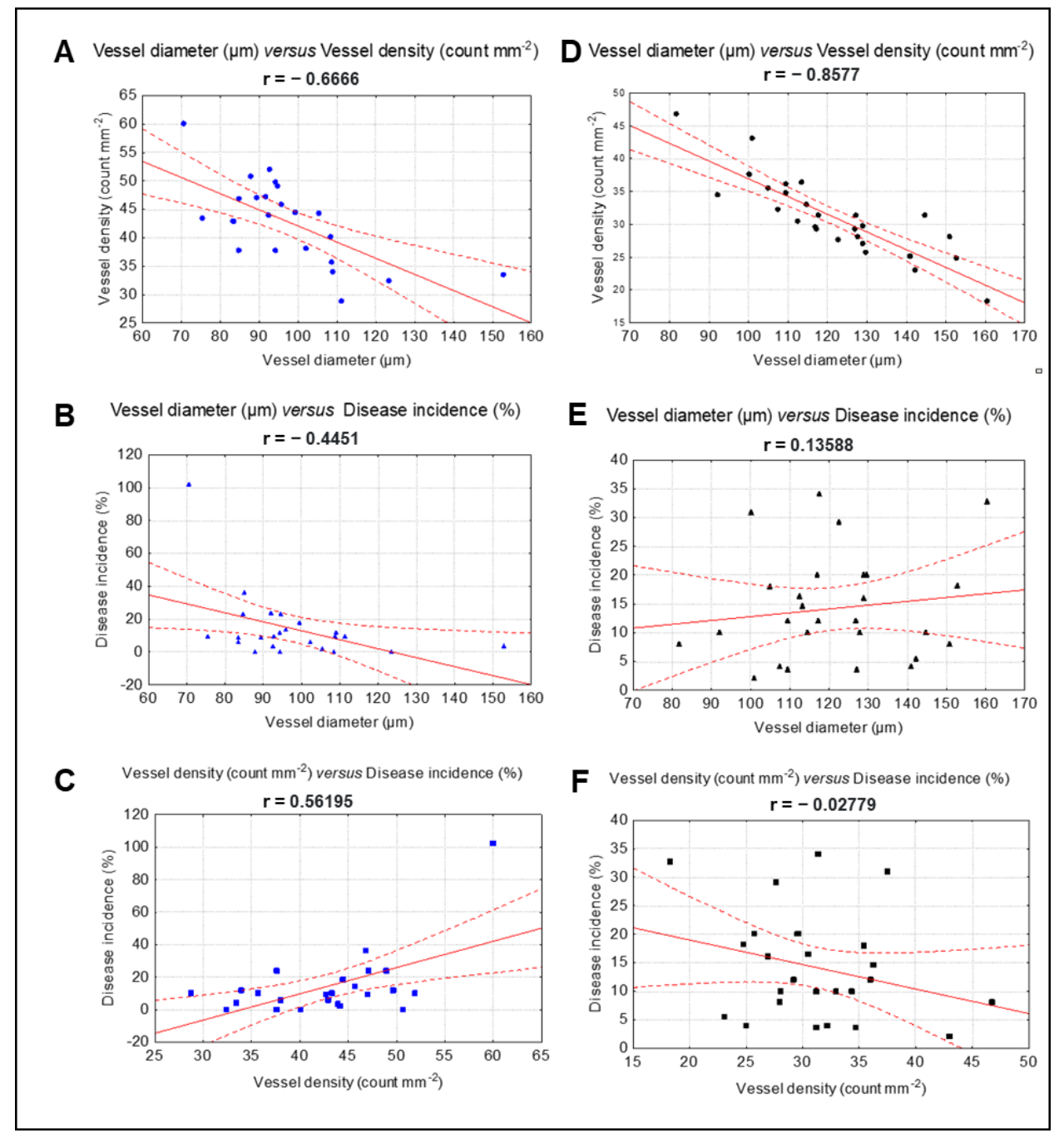

Figure 8. Pearson's correlations between vessel diameters and vessel densities (A,D), vessel diameters and disease incidence $(\mathbf{B}, \mathbf{E})$, and disease incidence and vessel densities $(\mathbf{C}, \mathbf{F})$ in the red-berried cultivars (A-C) and white-berried cultivars (D-F). 


\subsection{Comparisons among Red-Berried and White-Berried Cultivars}

Vessel diameter and vessel density-The comparison between red-berried and whiteberried cultivars highlighted significant differences between the two groups. The vessel diameter average values were $121.9 \mu \mathrm{m}$ for white-berried and $97.0 \mu \mathrm{m}$ for red-berried cultivars (Figure 9A). Regarding the vessel density, red-berried cultivars showed a higher density in comparison with the white-berried cultivars, with 42.8 vessels $\mathrm{mm}^{-2}$ and 31.0 vessels $\mathrm{mm}^{-2}$, respectively (Figure 9A).
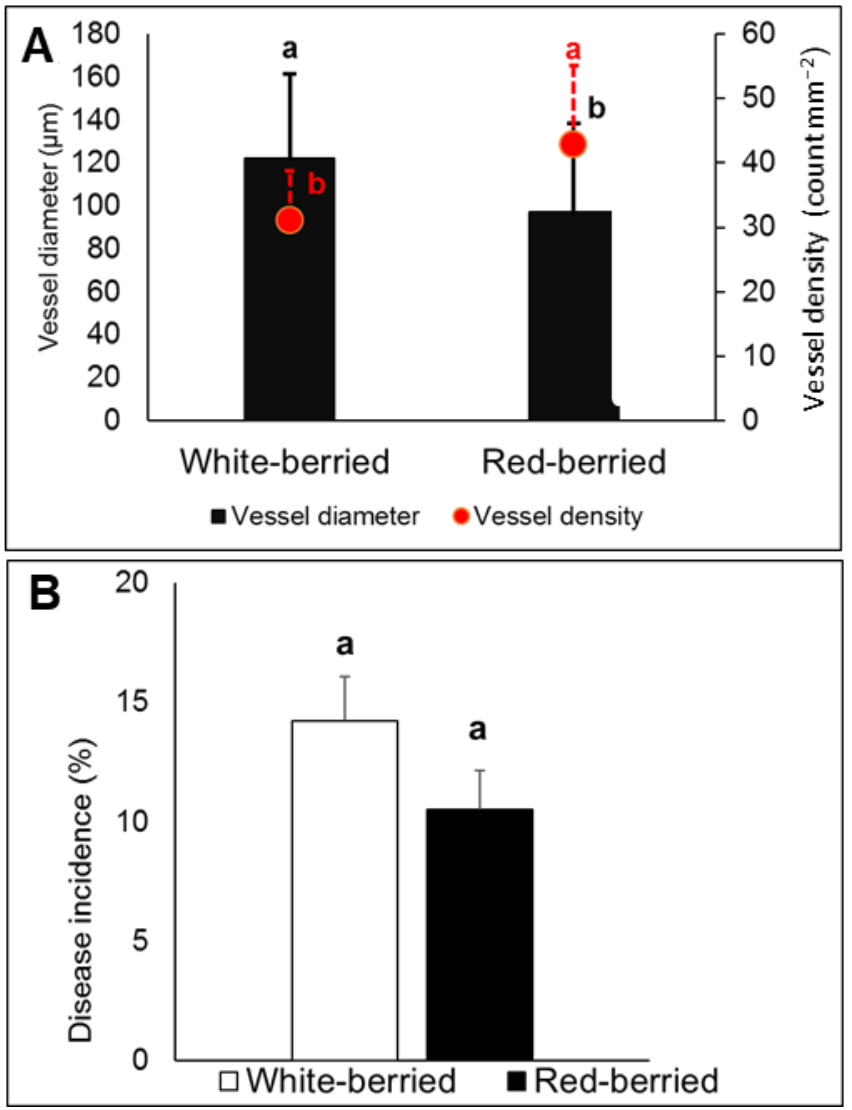

Figure 9. Comparisons between the xylem characteristics of vessel diameter (columns), and vessel density (circle) (A) and disease incidence (B) of the red-berried and white-berried cultivars of the grapevines. Data are means \pm standard deviation. Different letters above column indicate significant differences between cultivars (Fisher's tests; $p \leq 0.05$ ).

Disease incidence-A similar trend was observed among the red-berried and whiteberried cultivars relative to the overall disease incidence observed for the same cultivars, where the average disease incidence, as assessed by [22], was higher in the white-berried cultivars $(14.2 \%)$ than in the red-berried cultivars (10.5\%) (Figure 9B).

\section{Discussion}

Esca and other grapevine trunk diseases are one of the major limiting factors for grape production throughout the world [40]. In esca, which affects the trunk vascular tissues, information about the morphology of the xylem among grapevine cultivars will allow better understanding of the mechanisms of vascular pathogens. Previous studies have shown that the xylem vessel diameter differs among grapevine cultivars, and that these features might predict the degree of susceptibility of any given cultivar to vascular diseases [37]. Applying the methodologies used by [38], we investigated the main anatomical traits in xylem vessels in a wide range of grapevine genotypes, as 24 red-berried and 27 whiteberried cultivars with Italian national and international importance in viticulture. Some 
of these are spread worldwide, as reported by the International Organisation of Vine and Wine (OIV) [41]. The information gained here provides novel knowledge about the anatomical characteristics of xylem tissue in grapevine cultivars. In particular, our data showed high variability in both vessel diameter and vessel density within and among red-berried and white-berried cultivars grown in the field, emphasizing that the vessel dimensions can be affected by cultivar characteristics. The differences in vessel sizes and frequencies observed among the grapevine cultivars were in agreement with data reported in previous studies, which involved small numbers of cultivars grown in greenhouses. In particular, we observed similar vessel densities for the same cultivars previously analysed, i.e., 'Merlot', 'Chardonnay' and 'Cabernet Sauvignon' [34,37].

However, it should be emphasized that several studies carried out in a list of species have showed that the variation in xylem vessel size within genotypes changed across different environments [42-46]. These investigations showed that smaller vessels are advantageous to avoid freezing-induced embolism and to minimise the impact of droughtinduced cavitation. In peach rootstock, larger vessel sizes were found in the more vigorous rootstock than in the most dwarfing rootstock, and these characteristics were associated with the different hydraulic conductances estimated among these rootstocks [47]. Seasonal variations in vessel diameter are highly plastic and change with summer moisture availability, affecting plant growth $[48,49]$. However, several comparative studies underline that conductive path length is by far the main driver of variation in mean vessel diameter, suggesting that basipetal vessel size provides a useful methodological means of standardizing samples $[50,51]$. The present study analysed a large number of cultivars grown on the same experimental field, grafted onto the same rootstock, and trained with the same trellis system. For this reason, we can assume that external environmental factors, such as agricultural practices and soil and weather conditions, did not affect the results, which could instead be associated with grapevine genotypes. Interestingly, in this study, different distributions for the diameter classes were observed. In particular, there was a higher average vessel diameter in the white-berried cultivars compared to the average value detected in the red-berried cultivars. As might be predicted, a negative correlation was observed among the vessel diameters and vessel densities in both the white-berried and red-berried cultivars. Moreover, the lowest correlation coefficient was observed for the red-berried cultivars, which suggests less uniformity among this group regarding vessel size. To the best of our knowledge, the xylem anatomical properties associated with red-berried and white-berried cultivars represent new information in the field. However, further studies are needed to confirm these data and understand whether this anatomical feature has an important role in plant physiology or in plant-pathogen interactions. In this study we examined the relationship between these characteristics and incidence of esca symptoms, as previously assessed by [22] in the same experimental field for the same grapevine cultivars. For the relationships among vessel sizes and densities with esca incidence previously detected on the same grapevines, no linear relationship was observed for either the red-berried or white-berried cultivars. Previous investigation indicated that cultivars with larger vessels might be more susceptible to inoculated P. chlamydospora [34], one of the putative agents of esca, according to both pathogen concentration and wood necrosis lesions. In the present study, we referred to the esca symptoms observed in the field, which are known to involve several fungal species [5,11,52]. On the other hand, sometimes the presence of pathogens involved in esca was not resolved after the manifestation of symptoms. Grapevine trunk diseases have unpredictable discontinuity in the expression of foliar symptoms year by year $[2,8,53,54]$. Even after their first appearance, foliar symptoms do not develop systematically and cannot be predicted from year to year, which indicates that several factors, including the type of rootstock and environmental factors, are probably involved in their development [5]. However, a correspondence with esca susceptibility in some cultivars occurred in several works. The highest esca incidence was reported for 'Cabernet Sauvignon', 'Sangiovese', and 'Sauvignon Blanc', with lower incidence for 'Montepulciano' 'Merlot' and 'Chardonnay', [22,23,55,56]. Recent study yielded evidence that 
parenchyma cells play an active role during esca pathogenesis, expanding into the vessel lumen, secreting extracellular compounds, and eventually occluding the vessel, but no positive correlation between the severity of esca leaf symptoms and leaf vascular occlusions was observed. The authors suggested that symptom development was associated with vascular occlusions that are likely elicited at a distance from the pathogen niche localized in the trunk [57]. In our work, the overall average value of vessel diameter measured among the red-berried and white-berried cultivars showed that the white-berried cultivars have larger vessel sizes than the red-berried cultivars. A similar trend was observed among the red-berried and white-berried cultivars relative to the overall disease incidence observed by [22]. Then, although no significant relationship between disease incidence and xylem vessel dimensions was observed for the singular cultivars, the average values suggest a greater susceptibility of the white-berried cultivars that, according to our investigation, showed larger xylem vessel dimensions. Further investigations including a greater number of cultivars will be needed to verify this relationship. In this regard, the OIV [58] reported that in Italy the incidence of trunk disease depends on the varietal susceptibility: on plants of 15 to 18 years, corresponding to the age of plants analysed in this work, the average incidence can fluctuate from around $12 \%$ to $19 \%$ for the white-berried cultivars, and around $8 \%$ to $10 \%$ for the red-berried cultivars $[23,59]$. This suggests that some relationship among vessel dimensions and esca incidence might exist.

\section{Conclusions}

Our data represent a first step that can be useful for understanding the anatomical characteristics of the xylem of several grapevine cultivars. We have shown that there is a difference among cultivars regarding the size of xylem vessels in which the causal agents of esca develop, thus spreading the disease. The overall data detected in our study are interesting when compared in general with the incidence of the disease and represent important information, especially because this research involved a considerable number of grape cultivars. In esca, as for other trunk diseases, for the control of the diffusion of fungal pathogens in host tissues, the planting of cultivars resistant to wilt diseases remains one of the most durable and economically efficient control measures [28]. Our screening of vessel size properties linked to sensitivity of grapevine cultivars to esca disease can be useful for application innovative monitoring tools for identification of symptomatic plants in the vineyard [60]. For this reason, it becomes increasingly important to better understand the plant defence mechanisms and identify the less susceptible genotypes within the existing germplasms. These are key elements for sustainable agriculture.

Supplementary Materials: The following supporting information can be downloaded at: https:// www.mdpi.com/article/10.3390/app12031177/s1, Table S1. The list of cultivars analysed in this study including geographic origin from Vitis International Variety Catalogue database (www.vivc.de) [39].

Author Contributions: Conceptualization, G.R. and L.L.; methodology, R.F., L.L. and G.R.; software, L.L. and R.F.; funding acquisition, G.R.; validation, R.F., L.L. and G.R.; formal analysis, L.L. and R.F.; investigation, L.L. and R.F.; data curation, L.L. and R.F.; supervision, G.R.; writing-original draft preparation, L.L. and R.F.; writing-review and editing, L.L. and G.R. All authors have read and agreed to the published version of the manuscript.

Funding: This research was funded by the project "Understanding of epidemiology of esca disease" of Marche Polytechnic University.

Institutional Review Board Statement: Not applicable.

Informed Consent Statement: Not applicable.

Data Availability Statement: Not applicable.

Acknowledgments: Thanks are expressed to the project "Understanding of epidemiology of esca disease" funded by Marche Polytechnic University. Useful discussion with colleagues at meetings helped us to clarify the presentation of our results, and it is acknowledged and appreciated. 
Conflicts of Interest: The authors declare no conflict of interest.

\section{References}

1. Munkvold, G.P.; Duthie, J.A.; Marois, J.J. Reductions in yield and vegetative growth of grapevines due to Eutypa dieback. Phytopathology 1994, 84, 186-192. [CrossRef]

2. Mugnai, L.; Graniti, A.; Surico, G. Esca (Black measles) and brown wood-streaking: Two old and elusive diseases of grapevines. Plant Dis. 1999, 83, 404-418. [CrossRef] [PubMed]

3. Gramaje, D.; Armengol, J. Fungal trunk pathogens in the grapevine propagation process: Potential inoculum sources; detection; identification; and management strategies. Plant Dis. 2011, 95, 1040-1055. [CrossRef]

4. Lorrain, B.; Ky, I.; Pasquier, G.; Jourdes, M.; Dubrana, L.G.; Gény, L.; Rey, P.; Donèche, B.; Trissedre, P.L. Effect of esca disease on the phenolic and sensory attributes of Cabernet Sauvignon grapes; musts and wines. Aust. J. Grape Wine Res. 2012, $18,64-72$. [CrossRef]

5. Bertsch, C.; Ramirez-Suero, M.; Magnin-Robert, M.; Larignon, P.; Chong, J.; Abou-Mansour, A.E.; Spagnolo, C.; Fontaine, F. Grapevine trunk diseases: Complex and still poorly understood. Plant Pathol. 2013, 62, 243-265. [CrossRef]

6. Guerin-Dubrana, L.; Fontaine, F.; Mugnai, L. Grapevine trunk disease in European and Mediterranean vineyards: Occurrence, distribution and associated disease-affecting cultural factors. Phytopathol. Mediterr. 2019, 58, 49-71. [CrossRef]

7. Sosnowski, M.R.; Ayres, M.R.; Scott, E.S. The influence of water deficit stress on the grapevine trunk disease pathogens Eutypa lata and Diplodia seriata. Plant Dis. 2021, 105, 2217-2221. [CrossRef]

8. Romanazzi, G.; Murolo, S.; Pizzichini, L.; Nardi, S. Esca in young and mature vineyards; and molecular diagnosis of the associated fungi. Eur. J. Plant Pathol. 2009, 125, 277-290. [CrossRef]

9. Urbez-Torres, J.R. The status of Botryosphaeriaceae species infecting grapevines. Phytopathol. Mediterr. 2011, 50, S5-S45. [CrossRef]

10. Travadon, R.; Baumgartner, K.; Rolshausen, P.E.; Gubler, W.D.; Sosnowski, M.R.; Lecomte, P.; Halleen, F.; Péros, J.-P. Genetic structure of the fungal grapevine pathogen Eutypa lata from four continents. Plant Pathol. 2012, 61, 85-95. [CrossRef]

11. Úrbez-Torres, J.R.; Haag, P.; Bowen, P.; O'Gorman, D.T. Grapevine trunk diseases in British Columbia: Incidence and characterization of the fungal pathogens associated with esca and Petri diseases of grapevine. Plant Dis. 2014, 98, 456-468. [CrossRef] [PubMed]

12. Gramaje, D.; Mostert, L.; Groenewald, J.Z.; Crous, P.W. Phaeoacremonium: From esca disease to phaeohyphomycosis. Fungal Biol. 2015, 119, 759-783. [CrossRef] [PubMed]

13. González-Domínguez, E.; Berlanas, C.; Gramaje, D.; Armengol, J.; Rossi, V.; Berbegal, M. Temporal dispersal patterns of Phaeomoniella chlamydospora, causal agent of Petri disease and esca in vineyards. Phytopathology 2020, 110, 1216-1225. [CrossRef] [PubMed]

14. Rolshausen, P.E.; Urbez-Torres, J.R.; Rooney-Latham, S.; Eskalen, A.; Smith, R.J.; Gubler, W.D. Evaluation of pruning wound susceptibility and protection against fungi associated with grapevine trunk diseases. Am. J. Enol. Vitic. 2010, 61, 113-119.

15. Agustí-Brisach, C.; Gramaje, D.; Garcia-Jimenez, J.; Armengol, J. Detection of black-foot and Petri disease pathogens in soils of grapevine nurseries and vineyards using bait plants. Plant Soil 2013, 364, 5-13. [CrossRef]

16. Péros, J.P.; Berger, G. A rapid method to assess the aggressiveness of Eutypa lata isolates and the susceptibility of grapevine cultivar to Eutypa dieback. Agronomie 1994, 14, 515-523. [CrossRef]

17. Feliciano, A.J.; Eskalen, A.; Gubler, W.D. Differential susceptibility of three grapevine cultivars to Phaeoacremonium aleophilum and Phaeomoniella chlamydospora in California. Phytopathol. Mediterr. 2004, 43, 66-69. [CrossRef]

18. Christen, D.; Schonmann, S.; Jermini, M.; Strasser, R.J.; Defago, G. Characterization and early detection of grapevine (Vitis vinifera) stress responses to esca disease in situ chlorophyll fluorescence and comparison with drought stress. Environ. Exp. Bot. 2007, 60, 504-514. [CrossRef]

19. Landi, L.; Murolo, S.; Romanazzi, G. Colonization of Vitis spp. wood by sGFP-transformed Phaeomoniella chlamydospore, a tracheomycotic fungus involved in esca disease. Phytopathology 2012, 102, 290-297. [CrossRef]

20. Bruez, E.; Lecomte, P.; Grosman, J.; Doublet, B.; Bertsch, C.; Fontaine, F.; Ugaglia, A.; Trissedre, P.-L.; Da Costa, J.-P.; GuerinDubrana, L.; et al. Overview of grapevine trunk diseases in France in the 2000s. Phytopathol. Mediterr. 2013, 52, 262-275. [CrossRef]

21. Travadon, R.; Rolshausen, P.E.; Gubler, W.D.; Cadle-Davidson, L.; Baumgartner, K. Susceptibility of cultivated and wild Vitis spp. to wood infection by fungal trunk pathogens. Plant Dis. 2013, 97, 1529-1536. [CrossRef] [PubMed]

22. Murolo, S.; Romanazzi, G. Effects of grapevine cultivar; rootstock and clone on esca disease. Australas. Plant Pathol. 2014, 43, 215-221. [CrossRef]

23. Borgo, M.; Pegoraro, G.; Sartori, E. Susceptibility of grape varieties to esca disease. In Proceedings of the 39th World Congress of Vine and Wine BIO Web of Conferences, Bento Gonçalves, Brazil, 24-28 October 2016; Volume 7, p. 01041. [CrossRef]

24. Martínez-Diz, M.P.; Díaz-Losada, E.; Barajas, E.; Ruano-Rosa, D.; Andrés-Sodupe, M.; Gramaje, D. Screening of Spanish Vitis vinifera germplasm for resistance to Phaeomoniella chlamydospora. Sci. Hortic. 2019, 246, 104-109. [CrossRef]

25. Beckman, C.H.; Roberts, E.M. On the nature and genetic basis for resistance and tolerance to fungal wilt diseases of plants. Adv. Bot. Res. 1995, 21, 35-77. [CrossRef]

26. Talboys, P.W. Resistance to vascular wilt fungi. Proc. R. Soc. Lond. Ser. B. Biol. Sci. 1972, 181, 319-332. [CrossRef] 
27. Fradin, E.F.; Thomma, B.P.H.J. Physiology and molecular aspects of Verticillium wilt diseases caused by V. dahliae and V. albo-atrum. Mol. Plant Pathol. 2006, 7, 71-86. [CrossRef] [PubMed]

28. Yadeta, K.; Thomma, B.P.H.J. The xylem as battleground for plant hosts and vascular wilt pathogens. Front. Plant Sci. $2013,4,97$. [CrossRef] [PubMed]

29. Brasier, C.M. Ophiostoma novo-ulmi sp. nov. causative agent of current Dutch elm disease pandemics. Mycopathologia 1991, 115, 51-161. [CrossRef]

30. Solla, A.; Gil, L. Xylem vessel diameter as a factor in resistance of Ulmus minor to Ophiostoma novo-ulmi. For. Pathol. 2002, 32, 123-134. [CrossRef]

31. Venturas, M.; Lopez, R.; Martin, J.A.; Gasco, A.; Gil, L. Heritability of Ulmus minor resistance to Dutch elm disease and its relationship to vessel size, but not to xylem vulnerability to drought. Plant Pathol. 2014, 63, 500-509. [CrossRef]

32. Beier, G.L.; Lund, C.D.; Held, B.W.; Ploetz, R.C.; Konkol, J.L.; Blanchette, R.A. Variation in xylem characteristics of botanical races of Persea americana and their potential influence on susceptibility to the pathogen Raffaelea lauricola. Trop. Plant Pathol. 2020, 1-8. [CrossRef]

33. Deyett, E.; Pouzoulet, J.; Yang, J.I.; Ashworth, V.E.; Castro, C.; Roper, M.C.; Rolshausen, P.E. Assessment of Pierce's disease susceptibility in Vitis vinifera cultivars with different pedigrees. Plant Pathol. 2019, 68, 1079-1087. [CrossRef]

34. Pouzoulet, J.; Scudiero, E.; Schiavon, M.; Rolshausen, P.E. Xylem vessel diameter affects the compartmentalization of the vascular pathogen Phaeomoniella chlamydospora in grapevine. Front. Plant Sci. 2017, 8, 1442. [CrossRef] [PubMed]

35. Pouzoulet, J.; Scudiero, E.; Schiavon, M.; Santiago, L.S.; Rolshausen, P.E. Modeling of xylem vessel occlusion in grapevine. Tree Physiol. 2019, 39, 1438-1445. [CrossRef]

36. Pouzoulet, J.; Rolshausen, P.E.; Charbois, R.; Chen, J.; Guillaumie, S.; Ollat, N.; Gambetta, G.A.; Delmas, C.E.L. Behind the curtain of the compartmentalization process: Exploring how xylem vessel diameter impacts vascular pathogen resistance. Plant Cell Environ. 2020, 43, 2782-2796. [CrossRef]

37. Pouzoulet, J.; Pivovaroff, A.L.; Santiago, L.S.; Rolshausen, P.E. Can vessel dimension explain tolerance toward fungal vascular wilt diseases in woody plants? Lessons from Dutch elm disease and esca disease in grapevine. Front. Plant Sci. $2014,5,253$. [CrossRef]

38. Scholz, A.; Klepsch, M.; Karimi, Z.; Jansen, S. How to quantify conduits in wood? Front. Plant Sci. 2013, 4, 56. [CrossRef]

39. Maul, E.; Sudharma, K.N.; Ganesch, A.; Brühl, U.; Hundemer, M.; Kecke, S.; Mahler-Ries, A.; Marx, G.; Schreiber, T.; Walk, M.; et al. 30 years VIVC - Vitis International Variety Catalogue. In Proceedings of the XI International Conference on Grapevine Breeding and Genetics, Beijing, China, 28 July-2 August 2014; Available online: www.vivc.de (accessed on 11 November 2021).

40. Mohammadi, H.; Banihashemi, Z.; Gramaje, D.; Armengol, J. Fungal pathogens associated with grapevine trunk diseases in Iran. J. Agric. Sci. Technol. 2013, 15, 137-150.

41. Distribution of the World's Grapevine Varieties. In International Organization of Vine and Wine (OIV) Focus OIV 2017; OIV (Ed.) OIV: Paris, France, 2017; ISBN 9791091799898.

42. Fisher, J.B.; Goldstein, G.; Jones, T.J.; Cordell, S. Wood vessel diameter is related to elevation and genotype in the Hawaiian tree Metrosideros polymorpha (Myrtaceae). Am. J. Bot. 2007, 94, 709-715. [CrossRef]

43. Choat, B.; Medek, D.E.; Stuart, S.A.; Pasquet-Kok, J.; Egerton, J.J.; Salari, H.; Sack, L.; Ball, L.C. Xylem traits mediate a trade-off between resistance to freeze-thaw-induced embolism and photosynthetic capacity in overwintering evergreens. New Phytol. 2011, 191, 996-1005. [CrossRef]

44. Schreiber, S.G.; Hamann, A.; Hacke, U.G.; Thomas, B.R. Sixteen years of winter stress: An assessment of cold hardiness; growth performance and survival of hybrid poplar clones at a boreal planting site. Plant Cell Environ. 2013, 36, 419-428. [CrossRef] [PubMed]

45. Medeiros, J.S.; Pockman, W.T. Freezing regime and trade-offs with water transport efficiency generate variation in xylem structure across diploid populations of Larrea sp. (Zygophyllaceae). Am. J. Bot. 2014, 101, 598-607. [CrossRef] [PubMed]

46. Palliotti, A.; Tombesi, S.; Frioni, T.; Famiani, F.; Silvestroni, O.; Zamboni, M.; Poni, S. Morpho-structural and physiological response of container-grown Sangiovese and Montepulciano cvv. (Vitis vinifera) to re-watering after a pre-veraison limiting water deficit. Funct. Plant Biol. 2014, 41, 634-647. [CrossRef] [PubMed]

47. Tombesi, S.; Johnson, R.S.; Day, K.R.; De Jong, T.M. Relationships between xylem vessel characteristics; calculated axial hydraulic conductance and size-controlling capacity of peach rootstocks. Ann. Bot. 2010, 105, 327-331. [CrossRef]

48. Schreiber, S.G.; Hacke, U.G.; Hamann, A. Variation of xylem vessel diameters across a climate gradient: Insight from a reciprocal transplant experiment with a widespread boreal tree. Funct. Ecol. 2015, 29, 1392-1401. [CrossRef]

49. Qaderi, M.M.; Martel, A.B.; Dixon, S.L. Environmental factors influence plant vascular system and water regulation. Plants 2019, 8, 65. [CrossRef]

50. Rosell, J.A.; Olson, M.E.; Anfodillo, T. Scaling of xylem vessel diameter with plant size: Causes, predictions, and outstanding questions. Curr. For. Rep. 2017, 3, 46-59. [CrossRef]

51. Fajardo, A.; Martınez-Perez, C.; Cervantes-Alcayde, M.A.; Olson, M.E. Stem length, not climate, controls vessel diameter in two trees species across a sharp precipitation gradient. New Phytol. 2020, 225, 2347-2355. [CrossRef]

52. Bruno, G.; Sparapano, L. Effects of three esca-associated fungi on Vitis vinifera L.: V. Changes in the chemical and biological profile of xylem sap from diseased cv. Sangiovese vines. Physiol. Mol. Plant Pathol. 2007, 71, 210-229. [CrossRef] 
53. Surico, G.; Marchi, G.; Braccini, P.; Mugnai, L. Epidemiology of esca in some vineyards in Tuscany (Italy). Phytopathol. Mediterr. 2000, 39, 190-205. [CrossRef]

54. Wagschal, I.; Abou-Mansour, E.; Petit, A.N.; Clément, C.; Fontaine, F. Wood Diseases of Grapevine: A Review on Eutypa Dieback and Esca. In Plant-Microbe Interactions; Ait Barka, E., Clément, C., Eds.; Research Signpost: Kerala, India, 2008 ; pp. 367-391.

55. Marchi, M. Susceptibility to esca of various grapevine (Vitis vinifera) cultivars grafted on different rootstocks in a vineyard in the province of Siena (Italy). Phytopathol. Mediterr. 2001, 40, 27-36. [CrossRef]

56. Quaglia, M.; Covarelli, L.; Zazzerini, A. Epidemiological survey on esca disease in Umbria, central Italy. Phytopathol. Mediterr. 2009, 48, 84-91. [CrossRef]

57. Bortolami, G.; Gambetta, G.A.; Delzon, S.; Lamarque, L.J.; Pouzoulet, J.; Badel, E.; Burlett, R.; Charrier, G.; Cochard, H.; Dayer, S.; et al. Exploring the Hydraulic Failure Hy-pothesis of Esca Leaf Symptom Formation. Plant Physiol. 2019, 181, 1163-1174. [CrossRef] [PubMed]

58. Grapevine Trunk Diseases. A Review. In International Organization of Vine and Wine (OIV), 1st ed.; OIV (Ed.) OIV: Paris, France, 2016; ISBN 9791091799607.

59. Mondello, V.; Songy, A.; Battiston, E.; Pinto, C.; Coppin, C.; Trotel-Aziz, P.; Clément, C.; Mugnai, L.; Fontaine, F. Grapevine trunk diseases: A review of fifteen years of trials for their control with chemicals and biocontrol agents. Plant Dis. 2018, 102, 1189-1217. [CrossRef]

60. Falaschetti, L.; Manoni, L.; Calero Fuentes Rivera, R.; Pau, D.; Romanazzi, G.; Silvestroni, O.; Tomaselli, V.; Turchetti, C. A low-cost, low-power and real-time image detector for grape leaf esca disease based on a compressed CNN. IEEE J. Emerg. Sel. 2021, 11, 468-481. [CrossRef] 